\title{
The Process of Musical Translation: Composing a Maltese Festa Band March from Libyan Ma'lūf Music
}

\author{
Philip Ciantar / University of Malta
}

C urrent studies in language translation call attention to the fact that "the translation product per se only constitutes a mere surface manifestation of an entire dynamic array of conscious and unconscious mental processes that occur during the act of translation" (Garcia Alvarez 2007:139). In line with this, Holmes advocates further research into what happens in the translator's mind "as he creates a new, more or less matching text in another language" (2000:177). One assumes that what occurs in the translator's mind in the course of translation is very much dependent on factors that go beyond sheer competence; among these, one might mention the translator's experience, his or her assimilation of and interaction with the "source" and "target" languages, and any other cultural insights that would definitely serve as the basis for an accurate translation. All this may lead translators, among others, to adopt particular approaches and modes of thinking that they feel are more appropriate to the task at hand, while avoiding others.

As with language, "no music can exist without people who make it" (Powers 1980:8). Conversely, as with music, people can make language by being actively involved in various facets of its making - the movements of the mouth or hand, the sounds produced, and the activation of particular mental and psychological faculties in the course of understanding and interpretation. The common denominator in both domains remains the active role of the individual, who therefore deserves the utmost centrality at all stages of any inquiry concerning the two realms.

To some extent, some of the interrelated processes experienced by the individual in language translation may be akin to processes occurring in musical translation, the latter herein understood as the process by which the music

(C) 2013 by the Society for Ethnomusicology 
of others is comprehended, internalized, and, eventually, transformed in one's own musical consciousness. In this sense, musical translation may be among the complex layers that constitute the space between the self and the other, and therefore a vital issue of investigation for ethnomusicologists. As Bohlman observes, ethnomusicologists "cannot simply observe and describe the space between self and other, but rather they must enter it and deal with the complex forms of encounter that take place in it" (2002:37). Such complexity requires the ethnomusicologist to explore new ways of perception and understanding, not only by turning to other disciplines and the theories they propose, but also by reflecting introspectively upon his or her own position throughout the entire process of research. It is worth remarking here that the questions one needs to ask, the various approaches one may adopt in order to understand the process, the space within which that process occurs, and, eventually, the final product of musical translation are seemingly endless. This is accounted for by the diversity and complexity of practices adopted in recent research dealing with this area of study (Susam-Sarajeva 2008:191).

In this article, I will argue that the process of musical translation is sometimes triggered, motivated, shaped, constrained, and nurtured by a wide range of interrelated processes that may vary according to the translator's own recollections of the past, his or her present state as a member of a music tradition, and his or her interaction with and assimilation of both the "home" and "remote" musical traditions. In this sense, the translation process coalesces the self with the outside world that moulds it, the musical with the extra-musical, the sonic with the visual, and musical discourse with musical experience. In order to analyze this network of influencing factors, I examine the process as I experienced it myself when I decided to compose a Maltese festa band march with tunes from Libyan $m a^{\prime} l \bar{u} f$ music.

The word "festa" is the Maltese equivalent for "feast"; that is, a week or so of celebrations held annually in almost every Maltese town or village in honor of either its patron saint or secondary saint. ${ }^{1}$ In contrast with the Christian-oriented festa celebrations, the Libyan ma'lüf refers to music claimed to have been brought to Libya by Andalusian refugees fleeing the Christian reconquest of Spain in the tenth through seventeenth centuries. ${ }^{2}$ In Libya, especially in Tripoli (Libya's capital), ${ }^{3}$ the ma'lüf (meaning "well-known" and "popular") or al-ma'lüf, as it is more commonly referred to by the Libyans, can be heard in the context of Sufi celebrations as well as in its modernized form with ensembles composed of a choir accompanied by both Western and Arab instruments. ${ }^{4}$ Although the term ma'lüf refers mainly to the Andalusian North African nawba or song cycle, which therefore is specifically known as nawbat ma'lüf(that is, "the nawba of ma'lüf”), the term is also employed in Libya to refer to classical Arab music more widely as performed by professionally trained ensembles (firqāt). Therefore, when used 
in this sense, the term will encapsulate other Arab musical genres, such as the muwashsha and qașida, as well as classically arranged pieces of Libyan folk music.

My investigation into both music traditions, unfolded in this essay, will bring forth an array of processes that led to, engendered, and determined the interfacing of the "home" music tradition-that is, the Maltese festa band march tradition as I had experienced and assimilated it throughout my life as a native Maltese, a member of a bandsmen family, and, eventually, a bandsman myself-with the one "away" - that is, the Libyan music tradition of ma'lüf as I had understood and assimilated it through onsite fieldwork in Libya since May 2002, and later on through frequent listening to recordings I had brought home with me. The ethnomusicology of the present article, in an attempt to shed light on the seminal role of personal history in musical translation, combines a series of ethnographic snippets, from both away and at home, with some autoethnography.

My desire to compose a Maltese festa band march based on Libyan ma'lūf music goes back to my first encounters with the Libyan tradition. Although I made the initial drafts of this march three or four years ago, its full completion occurred in the course of the present writing, with sparse work having taken place from time to time in the interim, more as an expression of personal interest in composition than as a stern commitment. Nevertheless, the compositional process itself served as both an opportunity for some musical creativity and a chance to reflect on a process that has created an interface between two musical traditions which, although quite near geographically, are quite distanced culturally. Moreover, such a span of time provided me with the opportunity to delve into some autoethnography that brought together not only my positioning vis-à-vis the two traditions of our concern but also my own personal history as a member of one culture and a fieldworker in another, together with the events and circumstances that all this entailed. ${ }^{5}$

Although this is a case study relying on the experience of one individual at one particular time, and is shaped by particular situations in which I had found myself in both Malta and Libya, the scrutiny of the musical translation process as presented in the following discussion may shed light on similar processes that might have been experienced by composers worldwide in their attempts to interweave in some way the music of others with their own compositions. In this regard, examples from Western music are numerous, and range from Mozart's "Turkish Rondo" to Debussy's Javanese gamelan-inspired music for "Pagodes," and from Puccini's orientalism in Madame Butterfly to the Mediterraneanness in the music of the Maltese composer Charles Camilleri (1932-2009) in works such as the Maqām Piano Concerto. Other examples may also include compositions of popular music labeled as having Mediterranean inspiration, such as the music of the Valencian group Krama and the songs of the Greek singer Savina Yannatou. 
Recent projects in the domain of Mediterranean music that foster processes similar to the one being analyzed here include, for instance, summer music courses with a stream titled Etnomusicologia del Mediterraneaneo: Materia Prima per Una Nuova Musica (Ethnomusicology of the Mediterranean: Raw Material for a New Music), in which the transcription of traditional music from the Mediterranean serves as the basis for new compositions, performed at the end of the course. ${ }^{6}$ While the above projects put emphasis on the reasonable claim that culture influences music, the work of those who wear the hats of both ethnomusicologists documenting a tradition and composers appropriating the researched music for creative purposes channels us to the integrated recognition that music is also a cultural phenomenon, and therefore conscientious and sensible understanding of it can only be attained through interaction with the people in the field for whom that music exists profoundly.

With emphasis on a compositional process rooted in the theory and method of ethnomusicology and inspired by the initiatives mentioned above, the present article begins by describing the two music traditions of our concern with ethnographic depictions that will serve as points of reference later on in the discussion. Such vignettes introduce the reader to what Clifford refers to as "textualization"; that is, the process by which ethnography "translates experience into text" (1986:115). ${ }^{7}$ Following such an induction and the kind of ethnographic translation that goes with it, I consider the initial stages in the musical translation as presented here and what triggered the idea of composing a Maltese festa band march from the Libyan ma'lü. Since the process was stretched over a long time span, one can assume that some kind of motivation was in play; therefore, scrutiny of the motivation process itself should reveal some related insights. In the subsequent section, I discuss some technical aspects of the making of this march which led me, for instance, to opt for certain themes and not others, as well as to simplify some of these themes to fit nicely with not only the general style of the Maltese festa march but also particular performing practices idiosyncratic to Maltese wind band marching. Finally, I look into the reception of this march and how it relates to the politics of musical translation in the discovery of otherness.

\section{Festa Celebrations, Bands, and Marches}

With more than sixty feasts throughout the year (mostly during the summer months), and nearly twenty on the smaller sister island of Gozo, the Maltese festa tradition presents a fascinating festival of popular religious and secular celebrations. Such celebrations are marked by religious ceremonies, as well as boisterousness, firework displays, and band marching performed by either the wind band from the same village or town or a guest band from another locality. 
It is the time during which the religious and the secular coalesce conspicuously. Religious services in church are held simultaneously with outdoor activities that include band marching (see Figure 1), aerial fireworks, and church bells tolling, as well as the street cries of nougat vendors trying to capture the attention of passers-by, who might be people from the same village, visitors from other villages, or tourists. When referring to the religious and secular elements of a Maltese festa, Boissevain observes that "one can smell both incense and the gunpowder used in the fireworks" (1990:649) - a comment that can be taken both literally and metaphorically. For the villagers, the festa is "an occasion on which communal values are reaffirmed and strengthened, as individuals and groups express their loyalty to their patron saint and unite to defend and enhance the reputation of their village" (Boissevain 1993:59).

The preparations for the festa celebrations begin months ahead. The principal organizer of both church ( $t a^{\prime}$ gewwa) and street ( $t a^{\prime}$ barra) celebrations is the church, which, in coordination with the concerned village band club or clubs, works out a program of celebrations, commencing with the relocation of the Saint's statue from its accustomed niche to a central position in the same church. In terms of outdoor celebrations, this marks the beginning of an entire week of band marching and entertainment. However, the festa program reaches

Figure 1. A festa band march with the church in the background, July 2009.

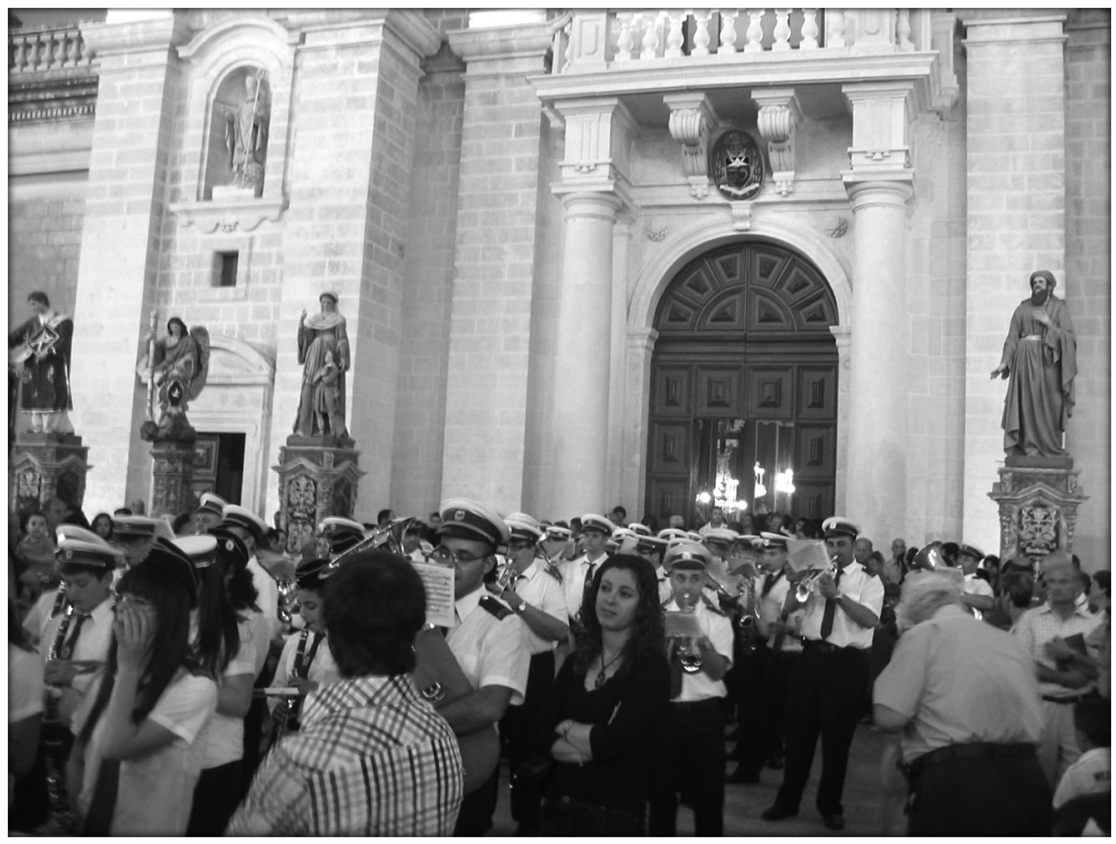


its culmination on the Sunday evening, when the statue of the Saint leaves the church in a procession around the streets of the town or village accompanied by band playing.

Malta holds a very strong tradition of wind band playing. This tradition goes back to the late 1840s when the first band was allegedly set up in the village of Zebbug under the direction of the blind musician Indrì Borg. The tradition continued to flourish through the presence in Malta of exiled Italian maestri who had fled the turbulence of the civil war in Italy during the nineteenth century and established residency in Malta. During their stay here, these Italian bandmasters had helped significantly in the dissemination of the tradition on the island, mainly by helping in the setting up and musical direction of newly established bands and by making arrangements of classical pieces for them. Moreover, the tradition had also benefited from the influence of British military bands seen parading along the streets of Maltese towns and villages. Since then, the band tradition has flourished enormously, so much so that nowadays in almost every Maltese town and village one finds from one to three band clubs supporting the feast of either the patron or secondary saint.

Band clubs are nowadays considered to be the most important secular societies in the villages, and recognized as "formally constituted associations with elected committees, premises of their own and a large body of dues-paying members drawn from all occupational and social classes" (Boissevain 1993:47). Their premises provide a place where club members meet every evening not only to discuss festa matters but also to update themselves with the latest village news, to feel a sense of belonging within a society that their families might have been affiliated with for years, and to discuss national politics. ${ }^{8}$

In some villages, competing band clubs co-evolved in continuous pique and direct confrontation, though they might be affiliated with the same feast. In this regard, Boissevain notes that these band clubs

... compete with each other over almost every aspect of their festas, from the decoration of the streets and the adornment of the statue to the number of guest bands and the quantity and quality of fireworks. Even the exact number ... and size of candles on the altars and the amount of light bulbs illuminating the facade of the church enter into the competition. (1964:1278)

There have sometimes developed strong rivalries between opposing clubs, with the police occasionally intervening to stop physical confrontations and the church authorities threatening to cancel-and sometimes even cancelling-all outdoor events. ${ }^{9}$

The role of band clubs in Maltese social and cultural life is central throughout the year, not just during festa week. This role varies from involvement in almost all village events to free weekly music teaching in the clubs' premises. Starting with the latter, band clubs provide free music tuition to young people aspiring to 
become bandsmen (most of the participants are men). To make up for the free tuition, the affiliated bandsmen will then give their musical services to the band for free. This reduces the money spent on the hiring of bandsmen from other bands, and consequently the expenditure for bands to play in public. Events such as the annual Good Friday pageant, the morning procession with the statue of the Risen Christ on Easter Sunday, the procession with a statue of Baby Jesus on Christmas Eve, and others held by a given local council would normally be accompanied by the village wind band playing music suitable for the occasion, chosen from a repertoire that varies from Christmas carols and Good Friday dirges to waltzes played during the Easter Sunday procession. However, the main annual event for a band remains the village festa, for which preparations start months in advance.

On the morning of festa day the band goes marching around the streets of the village playing lively marches composed by Maltese composers, accompanied by the boisterous loud singing and revelry of supporters and band aficionados, all united in the same communal sentiment. The morning march is very hectic indeed, with continuous loud playing that commences around nine in the morning and continues until two or three in the afternoon. During this march, the band stops from time to time for quick refreshment provided by supporting households. This provides participating bandsmen with the chance to pause in the five or so hours of playing, as well as to shelter themselves for a while from the strong summer sun (see Figure 2). In the meantime, the merrymaking of the supporters continues, with some supporters occasionally calling out for cold water to be poured on them from balconies and roofs of houses in the street to refresh them. Then, the band resumes its playing, with the selection of the march to be played next being decided by factors such as whether the person who composed or commissioned it lives in the vicinity or has been seen in the area.

Band marches are composed by the hundreds every year. The composition of these marches is for some aspiring young Maltese composers their first venture into musical composition. Some bands launch a new set of marches every year, while others do so biannually. New marches are sometimes commissioned, and eventually donated to the band, by supporters of the club, while others are donated by the composers themselves. A new set of marches is then recorded on $\mathrm{CD}$ and sold days ahead of festa week. Band marches played on car stereos during festa days provide a hint of which band club that car driver supports; in this sense, marches become indices of affiliation. Once a march becomes popular, the demand for it increases and, eventually, leads to its being sold to other band clubs. For some well-established local composers, the composition of band marches is both an extra income and a means by which to reaffirm and consolidate their status as maestri of the tradition. 
Figure 2. Band musicians having a break during a morning festa march parade, July 2009.

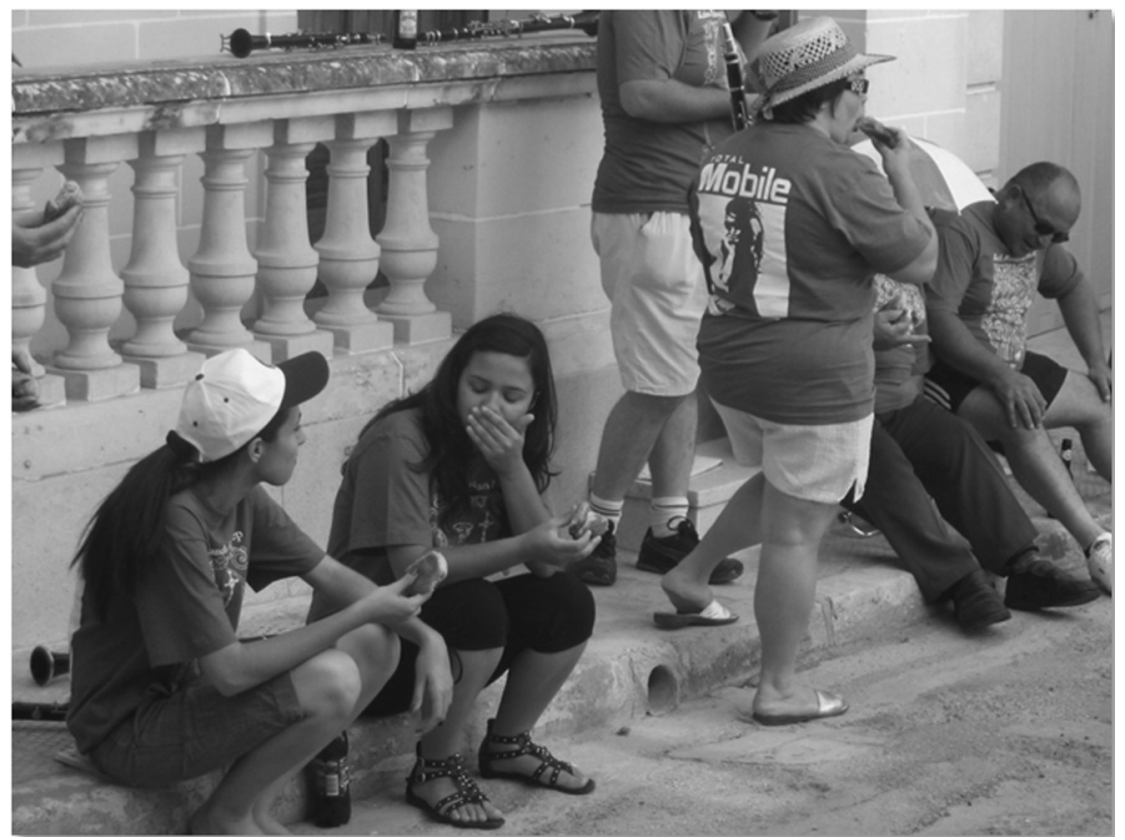

\section{The Libyan Ma'lūf Tradition}

As I have already indicated, the term ma'lüf as used in Libya refers to the nawba of ma'lūf as well as, more generally, to Arab classical music as performed by professionally trained ensembles. Commencing with the former, one can say that the nawbat ma'lūf exists in two main forms: the ma'lüf az-zāwiya, sometimes also called ma'lüf at-taqliydiy, and the ma'lüf al-idhäa. While the former refers to the traditional (taqliydiy means "traditional") ma'lüf of the nawba as performed in the context of Sufi lodges (zāwiya, pl. zawāya) or at related external ceremonies, the latter alludes to performances of the nawba as refined and disseminated by the recording or broadcasting industry (idhā'a means "broadcasting"). Although most Libyans think of the Libyan nawba as an "authentic" remnant of al-Andalus, anecdotes recounted to me by sheikhs ma'lüf (that is, masters of ma'lüf) about how Ottoman military tunes were transformed into nawba melodies and how Tunisian ma'lūf and non-ma'lūf melodies were integrated into the Libyan nawba repertoire contest this perception. ${ }^{10}$

Nevertheless, a nawba session is held in a zāwiya mainly during a hadrah (a Sufi religious ceremony), during which the nawba is preceded by readings from 
the qurān and a ritual known as dhikr (that is, invocation). Although performed in zāwiya all year round, the nawbat ma'lüf reaches its apex during a period in the Islamic calendar known as the mawlid, during which Muslims celebrate the birth of the Prophet Muhammad. On the morning of the first day of the mawlid period, Sufi brotherhoods gather in their respective zāwāya, situated in Tripoli's Medina l-Qadīyma (that is, Tripoli's Old City), to hold a hadrah which continues with a ma'lüf parade in the narrow streets of the Medina starting at around 10:00 a.m. Each of the three zawāya in the Medina holds its own parade according to a program agreed on in advance by the same three confraternities of the city. The first nawba sung by each of these parades is always nawba "Ya Muhammad" ("Oh Muhammad"), as it fits naturally with the spirit of mawlid celebrations. A ma'lüf parade is always headed by a sheikh ma'lüf assisted by the kinji (that is, his assistant) and a ghaytah (shawm) player. Behind them march the choristers followed by the tabl (a double-headed drum), naqqārāt (small kettle drums), and bandì (frame drum) players.

Throughout the parade, everybody seems to be united by the same fraternal sentiment generated by the nawba and the festivities of the mawlid (see Figure 3). Every now and then, participants are sprinkled with orange-blossom water and treated with mint tea and almond. The overall spirit is embellished with

Figure 3. A mawlid parade in Medina, Tripoli, May 2005.

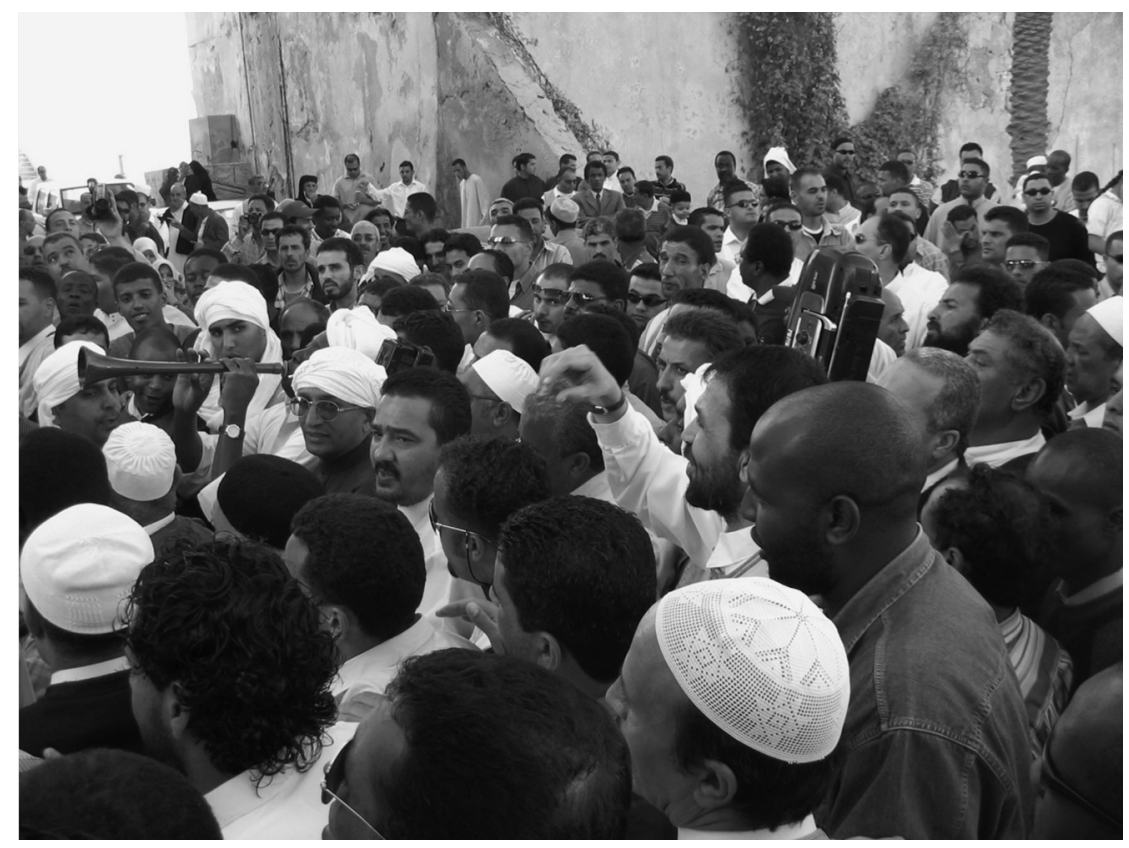


the ululations (known as zagharit) of women standing by the side and youths firing crackers in front of the parade. The long and slow-moving parade resumes and goes on until nine or so in the evening, when the confraternities return to their respective zawāya. Some Libyans prefer this raw ma'lūf not only for the "authentic" aura it holds but also for the context in which it is performed.

In contrast, the ma'lüf al-idhā'a presents different sonorities and set-ups from the ones just described. Such performances may be followed on Libyan TV, mainly through regular performances by the Libyan National Ma'luf Ensemble. ${ }^{11}$ The first Libyan ensemble of the ma'luff al-idhāa was set up in 1964 by the late Libyan ' $\bar{u} d$ (lute) player Hassan Araibi when he was an employee at the National Libyan Broadcasting Centre. Araibi established this ensemble on his return from Tunisia, where he had undergone training in the modern presentation of ma'lūf at the Rashidiyya Institute in Tunis. He restyled the nawba from one that employed several repetitions, calls, and responses to one relying more on chorality with fewer repeats (see Figure 4). This has consequently resulted in a shorter version that nowadays only takes from ten to fifteen minutes to complete, in contrast with that performed in zawāya, which normally takes three-quarters of an hour or so. Araibi's restyled nawba also included an instrumental prelude composed by him which replaced the istikhbār and istiftăh of the traditional

Figure 4. Hassan Araibi (front center) leading his ensemble, August 2004.

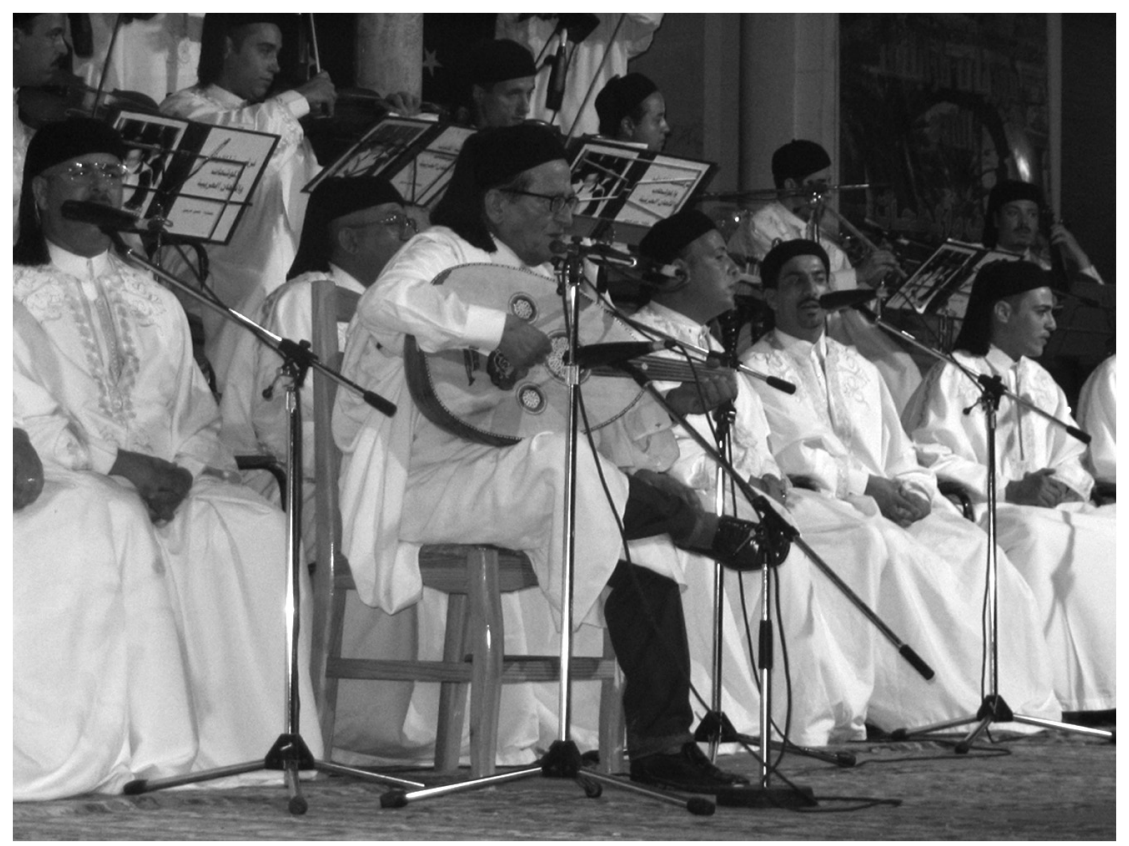


form, entrusted respectively to the ghayta and the solo voice of the sheikh. Some Libyans considered Araibi's compositions of these preludes as very unfitting to the nawba, and, to a certain extent, he is sometimes considered to have overtampered with what is believed to be authentic in this tradition. ${ }^{12}$

Apart from a choir, a modern ma'lüf ensemble includes both Western instruments (such as the violin, cello, and double bass) and Arab instruments such as the ' $\bar{u} d, q \bar{a} n \bar{u} n$ (trapezoidal zither), nāy (vertical end-blown flute), and darabukkah (a goblet drum). In addition to the nawbat ma'lüf, other genres performed during a ma'lūf al-idhāa program include arrangements of qașāàid, muwashshahāt, and Libyan folk music. During rehearsals of the Libyan Ma'lüf Ensemble I was able to note ample emphasis on aspects such as intonation, balance, strict adherence to tempo, and the right diction of words.

The state-sponsored Libyan Ma'lüf Ensemble is affiliated with the National Centre for the Research and Study of Arab Music, based in Tripoli. The Centre was chaired by Hassan Araibi from its foundation in the 1980s until his demise in April 2009. The ensemble employs singers and instrumentalists on a part-time basis, with professional instrumentalists trained in one of Libya's educational music institutions. A criterion for such professionalization is the ability of these instrumentalists to read musical notation. Proficiency in reading music is considered an asset for the ensemble due to the increasing demands of the recording industry. Knowledge of musical notation cuts down recording costs while at the same time upgrading the ensemble to a "truly" professional one, as some of the musicians have remarked to me. Six or seven years ago, the music performed by this ensemble was all played from memory, but in more recent times only the nawbat ma'lü is played from memory, with the rest of the repertoire all played from music parts.

\section{Initial Stimuli for Musical Translation}

My return from fieldwork meant not just sorting and documenting the collected data but also scrutinizing both onsite- and studio-recorded ma'lüf. The latter is mainly represented in the collection of fourteen cassettes recorded in 1993 by Hassan Araibi and his Ensemble, which is still the foremost example of the ma'lūf al-idhāa . Although the more I listened to ma'lūf the more I became acquainted with it, the idea to compose a Maltese festa band march based on this music had stemmed from two intertwined situations. Firstly, I was stimulated by the situations in which I had found myself during fieldwork, including the events for which I was present and the several formal and informal interviews I had with Libyan scholars of Arab music, Libyan musicians, and sheikhs ma'lūf, as well as people in grocery stores and taxi drivers. Secondly, I was stimulated by by my preoccupation with the field, not only with collecting the necessary 
data but also with attempting to attain an immediate understanding of the music to which I was listening and what it meant in its performance context. As ethnomusicologists faced with music alien to that at home, "we may marvel at the beauty of its simplicity or the cacophony produced by its complexity" while at the same time finding ourselves "lost in a search for meanings not immediately apparent or transformed through unexpected revelation" (Bohlman 2002:1). Circumstances in which we find ourselves as ethnomusicologists might forge, and to a certain extent determine, our understanding of the other music.

I consider the festive spirit I experienced on mawlid day as described above to have been seminal in this sense. In various respects, the overall ambience of mawlid day festivities was both sonically and visually akin to that of a Maltese festa march on a Sunday morning. Beginning with the sonic and its relation to the space of production, one can say that this helped me realize a similarity of acoustic space between performing venues in Malta and Libya. Schafer defines an acoustic space as "that volume of space in which the sound can be heard" (1977:214). The narrow streets of the medina and the high sound intensity produced there paralleled the loud playing typical of a Maltese festa band in the narrow streets of Maltese villages. One may also mention the sound of fireworks in both traditions and, on a more personal note, Sheikh Abu Sama's whispering voice opposing the modern practices by which, as he saw it, the youths in front of the procession were blatantly transforming a fundamentally religious celebration into a secular one. In a way, the Sheikh's preoccupation echoed the strong voice of the Catholic Church at home, with its appeals to band aficionados and supporters to elevate the Maltese festa from all paganism and mundane exaggeration to a celebration in which the spiritual predominates. In this type of situation, musical translation becomes more complex, as it includes not only the translation of the experienced sound but also of the entire experience encircling the sound, including the personal impressions left by the physical space and the unique sonority that evolves there, as well as the coalescence of past experiences and observations with new and/or recent ones. A particular scenario develops in which both the new and old within us become participants in the decoding of new symbols and symbolic systems. The transformation into language of this process follows the sequence proposed by Rice (1994:4) after Ricoeur's (1981:164): a "hermeneutical arc," but with music as substitute for text: “... [the hermeneutical arc] . . begins with pre-understanding, moves through explanation of the structure ... of music, to arrive at an interpretation and new understanding of the world referenced by music acting as a symbol."

An aspect of the music that attracted my attention at this initial stage was the voice and its centrality in the ma'lüf tradition. Michel Chion defines voicecentering as that process "by which, in a sound environment, the voice attracts and centers our attention, in the same way as the human face in the image of a film" 
(2000:206-07). In the ma'lüf, the centrality of the voice is melodically supported by melodies and rhythmically constrained by the need for the same words to be comprehended, as well as by internal structural constraints that facilitate group singing. In events such as the mawlid parade, the pronouncement of words is accompanied by hand movements in an attempt to bring out further, even visually, the meaning of the words pronounced (see Figure 5). Similarly, in the Maltese band marching tradition the voice plays a central role and, as in the ma'lüf, the pronouncement of words is accompanied by body movements. These movements range from the wide opening of arms high in the air with supporters lifted up on shoulders (see Figure 6) to the resting of the arms on each other's shoulders signaling unity as supporting members of the same band club.

The best Maltese marches, or, as the band aficionados refer to them, marci tal-widna, (i.e., marches with melodies pleasant to the ear), are the ones that are mostly set to words. In itself, the spontaneous singing they elicit presents an added example of the transformation of music affect into something else, such as in dancing and trance. The march melodies to which words are set are melodies that are rhythmically less intricate than others, allowing for a smooth merger of the voice with the music, while melodically they adhere to well-shaped phrases.

Figure 5. Hand movements with the pronouncement of ma'lüf text during a mawlid parade, May 2005.

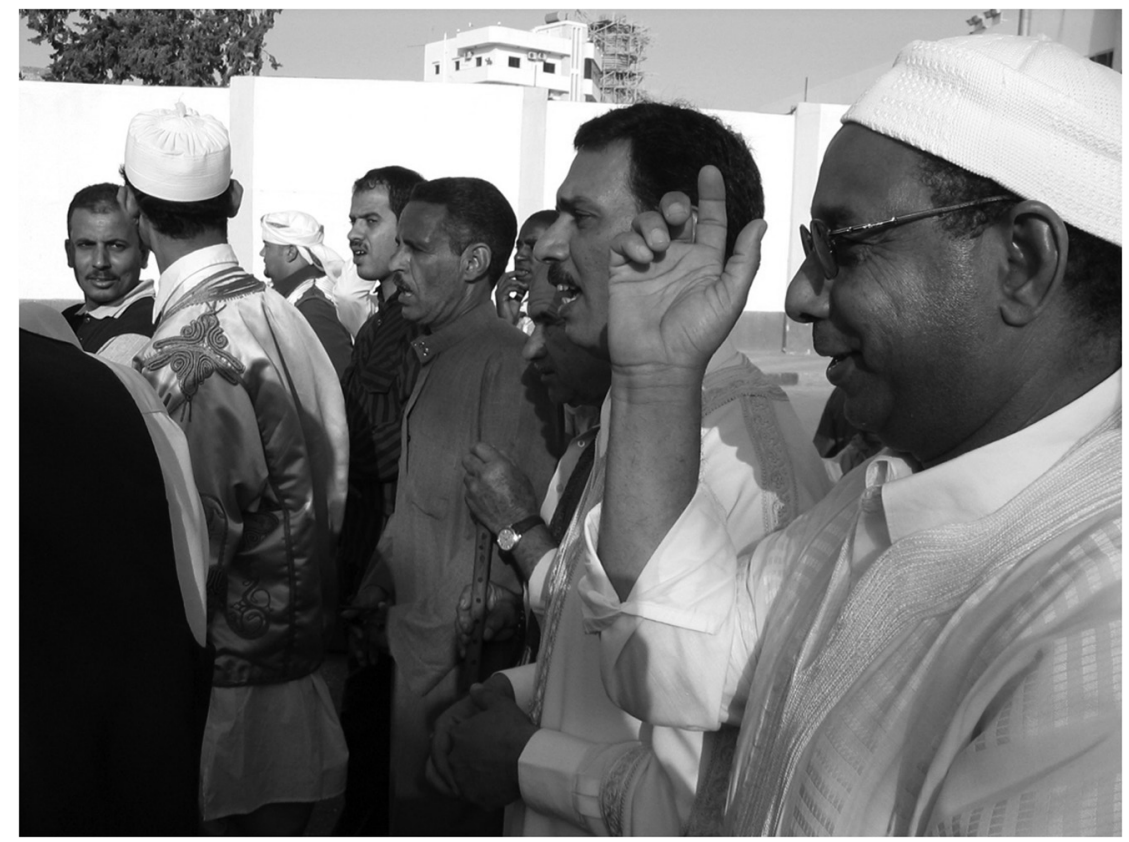


Figure 6. Supporters lifted up on the shoulders with arms high in the air, July 2009.

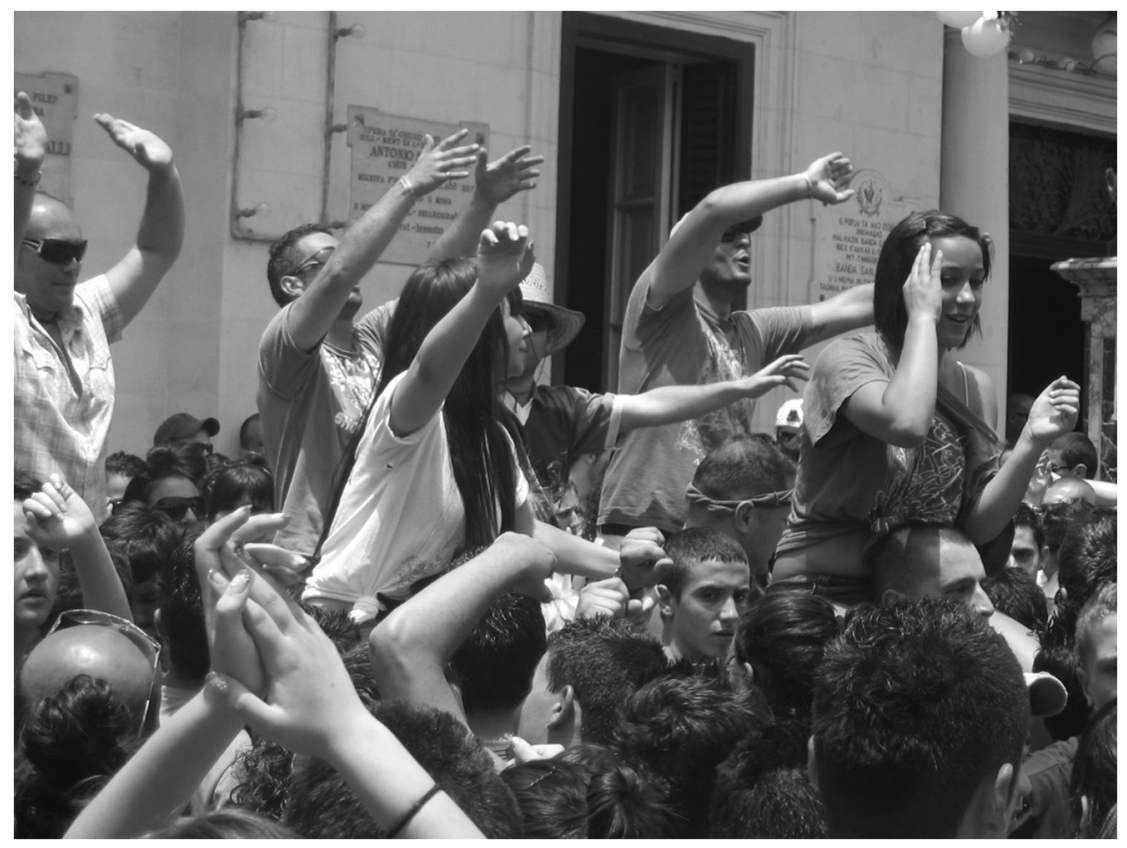

As mentioned earlier, the visual aspect of the mawlid celebrations also influenced me to attempt translation. Paradoxically, the sonic attained its fullest meaning when embedded in the visual. As Susam-Sarajeva notes, the two are inseparable: "music goes hand in hand with evocative associations, settings and visual imagery" (2008:190). The sound patterns emerging in the highly active environment of the medina were just one of the "several communication channels" (Finnegan 2003:191) I had experienced during that event. An equally important channel that had highlighted further parallels between the two traditions was the visual. The distribution of drinks and food during the mawlid parade could not but remind me of Maltese bandsmen helping themselves to the food and drinks provided to them during the Sunday morning march as described above. Moreover, the depiction of highly esteemed families in the medina sprinkling orange blossom water from atop balconies and doorsteps seemed to me analogous to the water being sprinkled on supporters during the mass hysteria generated during the Sunday morning marching parade. A hypothesis worth investigating here, then, is that the visual is fundamental to musical translation, and whether experienced in real events or just imagined or fantasized, its presence at some stage of the process seems inevitable. Ethnographic commentary 
attests to the impact on ethnomusicologists of the visual, and to the prominent role their understanding and interpretation of it plays in their accounts of the multiple realities and politics underlying the dramaturgy of performance and all that makes it and surrounds it.

The initial stage of the translation process was to some extent influenced by what my informants had to say about the authenticity of ma'lūf. For instance, Abdalla Sebai, a retired Professor of Arab musicology at al-Fātih University (Tripoli), explained to me how certain melodies of the nawbat ma'lüf suggest expert music making such as that produced by the military bands which were regularly seen marching in the streets of Tripoli during the Ottoman occupancy. Melodies such as that of nawba "nāh al-hamām" (The Pigeons' Lament) were singled out by the same informant in this regard: "It resembles an Ottoman military march," he told me. In addition, Sheikhs ma'lüf such as Sheikh Gheddur Afandi are still remembered by ma'lüf aficionados as the ones who had employed Ottoman melodies in the Libyan nawba. ${ }^{13}$ How people think and speak about their music is crucial, as this may generate or restrain musical translation both intra- and inter-culturally.

My process of musical translation and the resultant unique interfacing of the two musical traditions it concerned were in part a response to my urgent need to make sense of whatever was occurring around me, including the music making and the sound to which I was being exposed. The acquisition of fieldwork data, including sonic data and the immediate understanding it provided, on which I could construct a wider perspective of the ma'lüf tradition was a major concern to me through which I could reach out for further understanding of new material. However, if one situates this personal preoccupation within the wider phenomenon of musical listening, it is apparent that my eagerness for immediate understanding was very natural and also very much like the results of similar listening experiences in which the listener is insufficiently informed. In this regard, Dibben notes that:

Where the immediate information from the perceptual source (e.g., sound) is insufficient, the listener searches for additional information from the social and cultural environment: by observing the behaviour of others, by discussions with others, and by exploring the music through the discourse and other information that surrounds it. (2003:202)

Dibben's assertion brings together all the initial stimuli for musical translation laid out above. In this context, musical translation may arise from the need and preoccupation of an individual to make urgent sense of a new listening experience; this individual's reliance on all possible reachable information to satisfy that need would result in comparison and consequently translation.

In all this, one descries a psychological process referred to by Kim as the "stress-adaptation-growth dynamic," a process characterized by a "conflict be- 
tween the natural inertia of old mental habits and the inherent drive to maximize life chances by adapting to new ways of dealing with unfamiliar challenges" (2000:61). This conflict, as Kim (ibid.) points out, may be loaded with stressful events that in themselves activate "adaptive energy" in the researcher, for the purpose of reorganizing the psyche and moving forward. To understand new cultural elements and respond to the demands of intercultural contacts requires adjustments to our existing internal structure, with efforts in this direction becoming fundamental also to musical translation. This explains the degree of readiness that permits an individual to get involved with the diverse processes implied by cultural translation. Such readiness serves as basis on which the individual harmonizes the self, and all that constitutes it, with the world outside and the impressions that this leaves on him or her.

\section{Musical Translation and Motivation}

In my introduction, I have pointed out that my composition of the march in question occurred sparsely over a period of three or four years. In itself, this shows that some kind of motivation to pursue the task was in play; otherwise, I would not have persisted with it. Theories of motivation recognize persistence as an index of motivation (see, for instance, Beck 1978:30-31), and mine is a case in point. Musical translation could also be the result of motivation being intrinsic and/or extrinsic.

Two factors motivated me to persist with the task: first was the duty I felt to give something back to the tradition from which I grew, and second, but of no less importance, was the desire to share melodies I had started to like, mainly through repetitive listening in the course of transcription, which could never have been accepted by my tradition in their untranslated form. While the former factor relates strongly to my place in the Maltese band tradition, the latter stems from recognition of a cultural and political scenario that for ages had been part of a continuous conflict between the uncontested European and the equivocal Arab segment of Maltese culture, with the latter sometimes construed as a threat to Malta's European identity. Indeed, political discourse about Malta's Euro-Mediterranean “vocation” had turned, especially after Malta's accession into the European Union in 2004, to favor its political position with the Western block rather than the Eastern one.

My earliest exposure to the band tradition goes back to my childhood as a member of a family of band musicians, with my father and three of my five siblings all playing band instruments and composing commissioned marches. It seemed as if it was my natural destiny to start learning a band instrument, and eventually earn some money by playing in bands. My life as a trombonist in village bands was quite active, and in a way very fruitful in terms of musical experience, exposure, and financial attainment. However, my eventual partici- 
pation in local orchestral playing, and attendant recognition of a "professional" versus "amateur" dichotomy began to distance me from an environment considered by the high echelons of Maltese music to be amateurish, which therefore seemed to me to be a threat to my induction into the local sphere of musical professionalism. Eventually, I ended all musical commitments with local bands in pursuit of my "professional" (whatever that meant) safeguard. At this stage, I must point out that my decisions should be understood in the context of a small insular island, where a geographical claustrophobia is regularly transformed into a social one, with the politics of the local artistic network very much dictated by all this.

Composing a band march and giving something popular to the tradition in which I was brought up but from which I had distanced myself seemed a means of getting back to the band tradition-a means of reconciliation with a musical tradition from which I had benefited very much. Coinciding with these feelings was a comment by a local bandmaster and one-time fellow bandsman, who, during a teachers' seminar in which I was participating, complained that local bands were getting no benefit from musicians who had attained so much from the band tradition. Once they had progressed musically, he suggested, "you won't see them around any longer." I have not yet determined whether this comment was directed at me personally or whether it was meant as a general commentary on an awkward local situation. However, I do admit that it served to sustain and, in a way, cause me to persist with my attempt at rapprochement.

Another motivational factor that sustained the process was the promise of seeing band supporters boisterously enjoy themselves with music fundamentally oriental, and therefore contestable in the context of Malta's insistence on its European identity and, by extension, on its Christian cultural roots. ${ }^{14} \mathrm{In}$ itself, this was a cynical attitude, stemming from an insider's recognition of the ideological forces that continuously vie with each other on the island. The transformation of Libyan ma'lūf music into a Maltese band march seemed to me to be a shortcut to the insertion into a Christian-related celebration of a musical genre that could hardly ever be accepted within that context, as well as into a cultural and political scenario in which whatever evokes the "primitive" or "backward" orient is sometimes considered a threat to Malta's European identity, especially now that Malta is a member of the European Union. Locally, Malta's 2003 accession to the EU signified the confirmation, as a political and economic reality, of the majority's cultural affiliation. In this cultural, political, and ideological scenario, appreciation of the Libyan ma'lüf seemed to me as if it could only occur in translation. This would be common process, if one agrees with Russian philologist Vladimir Toporov that culture is not only a "place where meanings are born, but [also a] space in which [meanings are] exchanged, 'transmitted' and seek to be translated from one cultural language into another" (quoted in Torop 2003:276). 


\section{A Festa Band March in the Making}

The compositional process was essentially a political as well as a personal preoccupation, though this was camouflaged by the predominantly musical. Technically, there was the selection of particular themes from the Libyan ma'lüf which had stood out as special to me and which I thought would sound very good in the general style of a Maltese band march. Moreover, cultural sensitivity toward and awareness of both my own music and the one away led to a series of conscious and/or unconscious efforts on my part to smooth out cultural gaps through a composition that, while aiming to maintain some degree of faithfulness to the original versions of its source material, would not evolve at odds with what band aficionados expect of a Maltese festa march. In this sense, my composition was a political act that also strove to sustain the discreet visibility of the musical.

I gave the march the title of "Il-Maghruf," which is the Maltese equivalent to al-ma'lūf. ${ }^{15}$ Maltese band marches with distinctive titles are very common. These titles range from those referring to family nicknames to others inspired by the "exotic" world, as in march titles such as "Peking," "Chinese Roses," and "Arabian Nights." Maltese band marches employing an "exotic" style are few, and, according to one local march composer, it is hard to determine the use of authentic tunes in them:

These composers might have visited the country and perhaps got inspired by the place and its music. Perhaps imitating some authentic tunes? I don't know! But, I guess, they hardly bothered about reproducing authentic tunes as you're trying to do. They would have probably got the gist of what they have heard that's all ... (personal communication, 2 April 2012, Malta) ${ }^{16}$

Other march titles suggest allusions to supremacy in popularity such as "The King," and, in response to that, "The King of Kings." In the subtitle to my march, I acknowledged prominently the source of the themes from which I have derived the melodic material, and therefore indicated that the themes were from Libya (ghanjiet mil-Libja-tunes from Libya). In the context of Maltese band marches, the acknowledgement of sources when this applies is definitely out of the question, even when melodic material is evidently derived from such sources, as from Italian popular songs such as "Arrivederci Roma" or traditional English nursery rhymes such as "Rock-a-bye Baby." However, it seemed to me that full acknowledgement of the source from which the themes were brought was extremely important not only for ethical correctness but also in full awareness of a world in which the rate of music diffusion through cyberspace far exceeds the rate of movement around the globe of both music makers and consumers.

Maltese festa marches, like band marches in general, are characterised by a strong repetitive rhythm and an uncomplicated style. They present stylistic traits common to marches throughout their history, especially marches that include 
"rhythmic patterns with regularly recurring accents built into phrases or periods, straightforward harmonies and textures, and unpretentious but often memorable melodies" (Schwandt 2001:813). The structure of Maltese band marches accentuates symmetrically constructed melodies within evenly bared strains in which the second part repeats the first in a higher register, with the employment of the full band and a countermelody. This repetition generates a kind of balance between moments of composure and elation throughout the entire march. Such balance is experienced at some length in the last strain of the march, known as the "trio," so-called for its contrasting and melodious character which, according to an established practice, should always unfold in a major key.

No matter my efforts to maintain their original versions, the themes I had decided to use each required some degree of modification, whether due to extramusical exigencies that I had to consider on the basis of my own experience in band playing or to make them fit the style and sometimes the structural constraints of the Maltese march. An example of the former consideration is the introduction to the march, based on Hassan Araibi's instrumental prelude to nawba jamru l-hawa, as featured in his recorded collection. I had to modify this theme to make it more playable in marching situations, where, for instance, poor lighting during evening parades can make part-reading difficult. From my personal experience I knew that a melodic line loaded with sixteenth-note groupings was basically impractical in the performing situations just described; such an impracticality could result in the march remaining very low in terms of popularity and dissemination in the local band march market. Figure 7 a shows the theme as transcribed from the cassette recording of the Libyan Ensemble, while Figure $7 \mathrm{~b}$ shows how the framed passages were simplified to secure a stable march introduction even under uncomfortable performing conditions. The same example shows how the lengthy sequences of sixteenth-notes were replaced by fitting syncopated phrases. Syncopation is very common in Maltese marches, since many local march composers believe that it is well liked by band aficionados; this also influenced my decision to make use of it.

Figure 7a. Instrumental prelude (composed by Hassan Araibi) to Nawba Jamrul-Hawā.

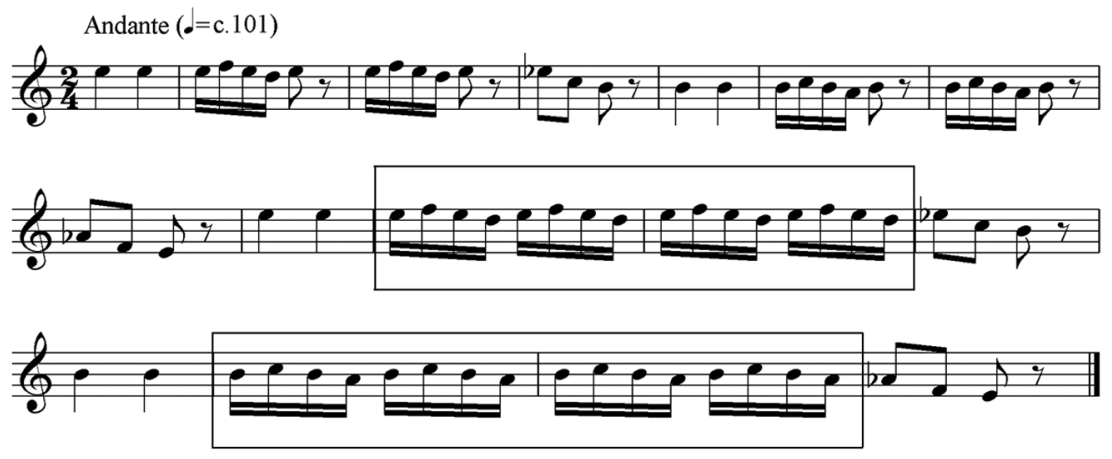


Figure 7b. Extract from the Introduction to Il-Maghruf(in reduced score), showing points of simplification (framed).

Allegro $\left(\sigma_{-} \mathrm{c} .110\right)$
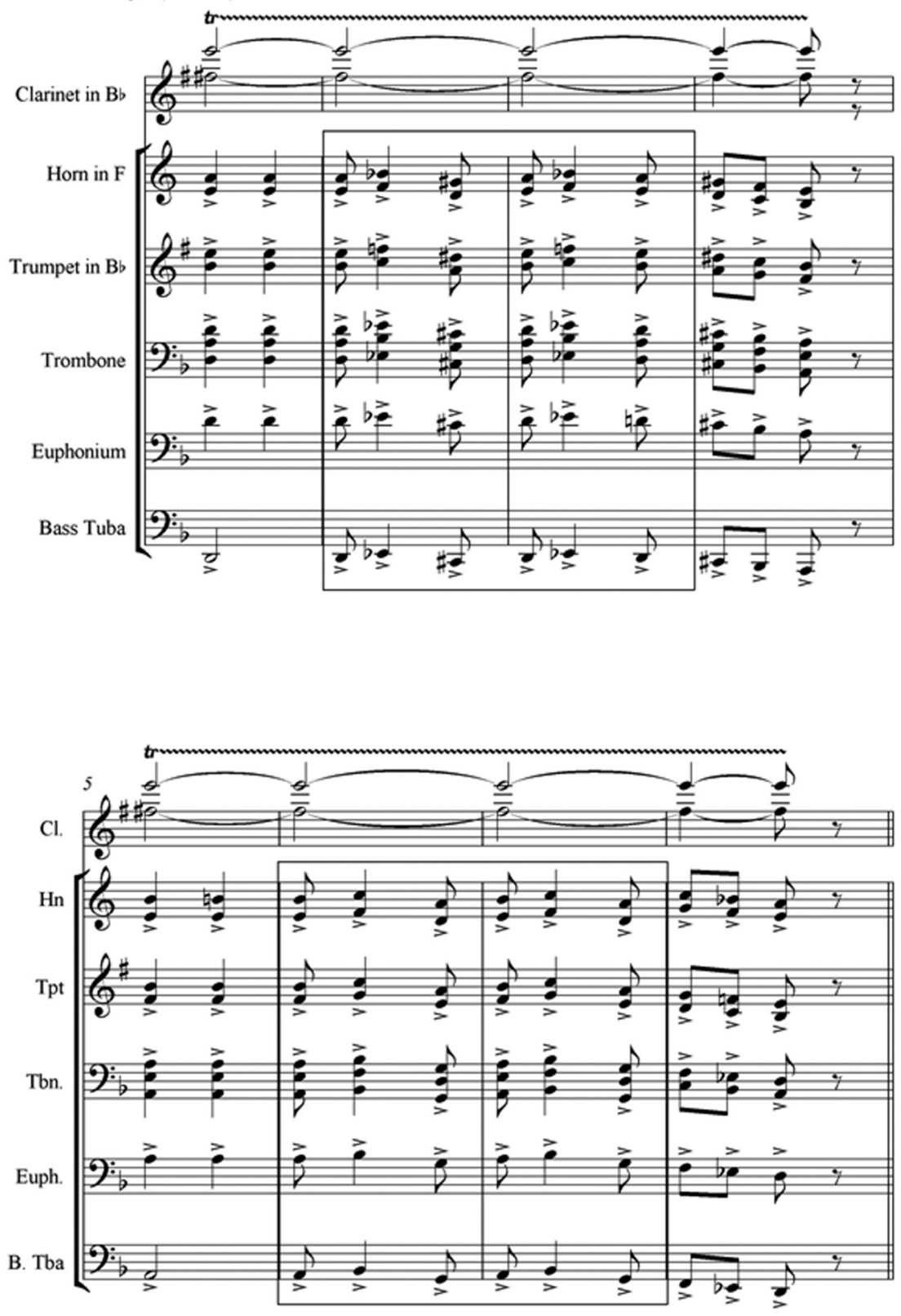
Frequent performance of a piece, caused by its central place within a repertoire, can have the consequence that through repeated hearings it becomes more appealing to people both within and outside its traditional arena of performance. Nawba nāh al-hamām presents a case in point. The importance of this nawba in the ma'lüf repertoire emerges from its conclusive positioning at the end of both Sufi ma'lūf performances and others held by modern ensembles such as Araibi's. Equipped with knowledge pertaining to the place of this nawba, both within the Libyan nawba repertoire and ma'lüf performances more widely, and its inherent marching qualities (due to its possible derivation from Ottoman military music, as explained above), I decided to extract a theme (see Figure 8a) from it which, in line with its typical place in the Libyan tradition, I assigned to the last and most prominent strain of the march - the trio. Considerations of Maltese march structure, foremost being the highly symmetrical construction of the melodic line and the presence of a bridge between the first and second parts of the trio, constrained me to limit my melodic extraction to just the opening few bars of the original theme, though I wished I could employ it in its entirety. Another adaptation evident in this example and others to follow is the change from the ${ }_{4}^{8}$ or ${ }_{8}^{8}$ meters employed in the nawba to the ${ }_{4}^{2}$ of the Maltese march. ${ }^{17}$ Figure $8 \mathrm{~b}$, for instance, demonstrates how the original theme was redesigned to fit into the trio not only in terms of meter, but also in terms of style and structure. The latter considerations necessitated the amalgamation of non-ma'lüf material (framed) with the original theme, so that the listener would experience more frequent and evident shifts between antecedent and consequent phrases that themselves would anticipate the bridge and the eventual repetition of the first part.

The level of melodic adaptability from the original varied according to the intrinsic character of the borrowed themes; the theme of the first section, for instance, which I derived from muwashshah salfiy ad-dhaläm, is a good example of this. This muwashshah is one of the pieces most frequently performed by Araibi's ensemble (see Figure 9a). ${ }^{18}$ Indeed, the more I heard it the more I liked it, and eventually it became one of my favorites, tempting me whenever I opened Araibi's cassette collection. It was also special to me as the first piece that I heard being performed live by Araibi's Ensemble, during a recording session at Qatar al-Fajar

Figure 8a. Theme from Nawba Nah al-Hamām.

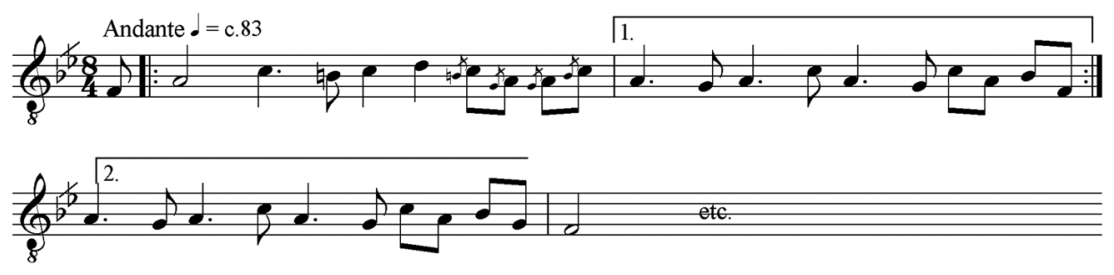


Figure $8 \mathrm{~b}$. Second part of the Trio.
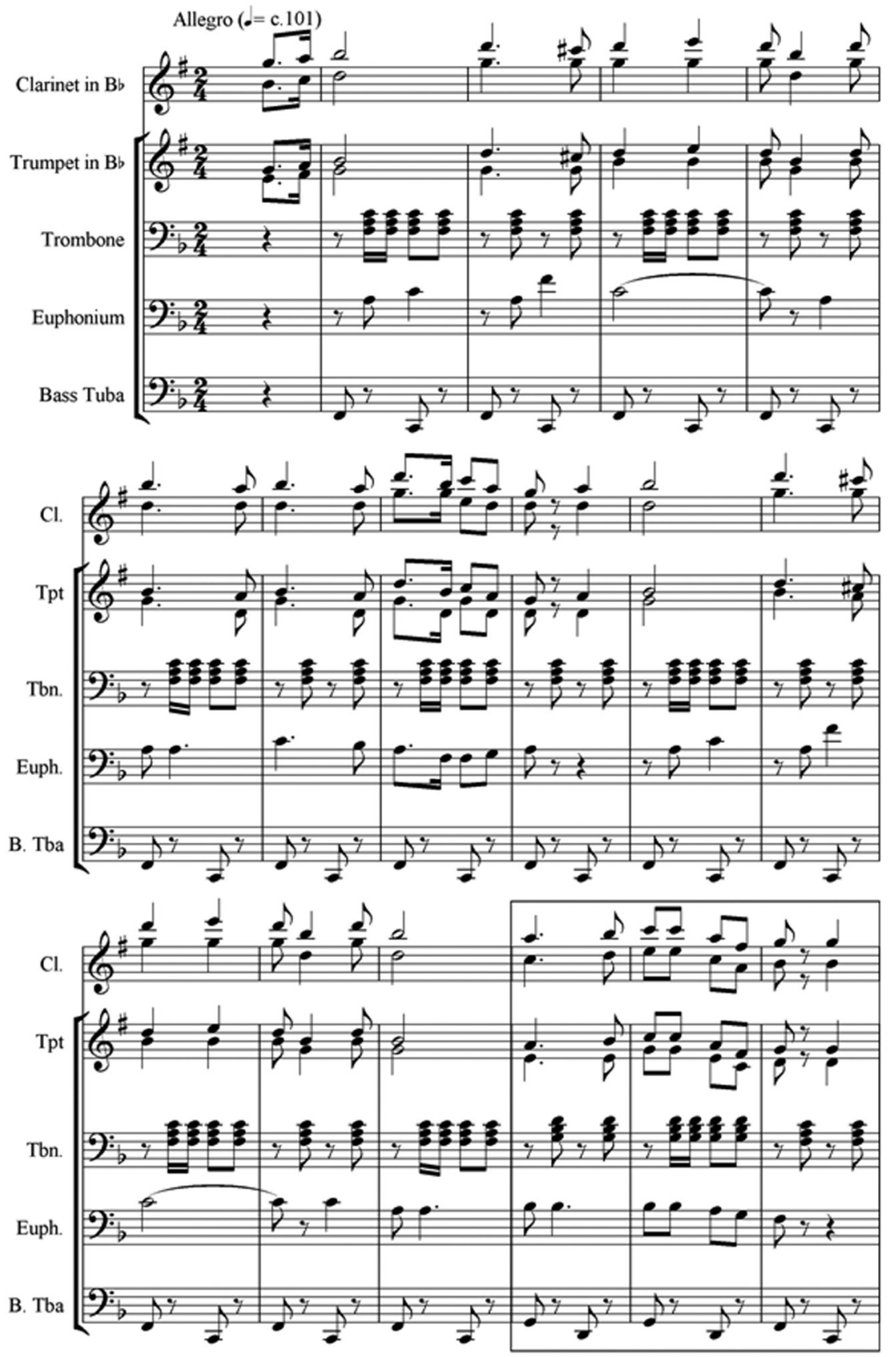
Figure 8b.(cont.)

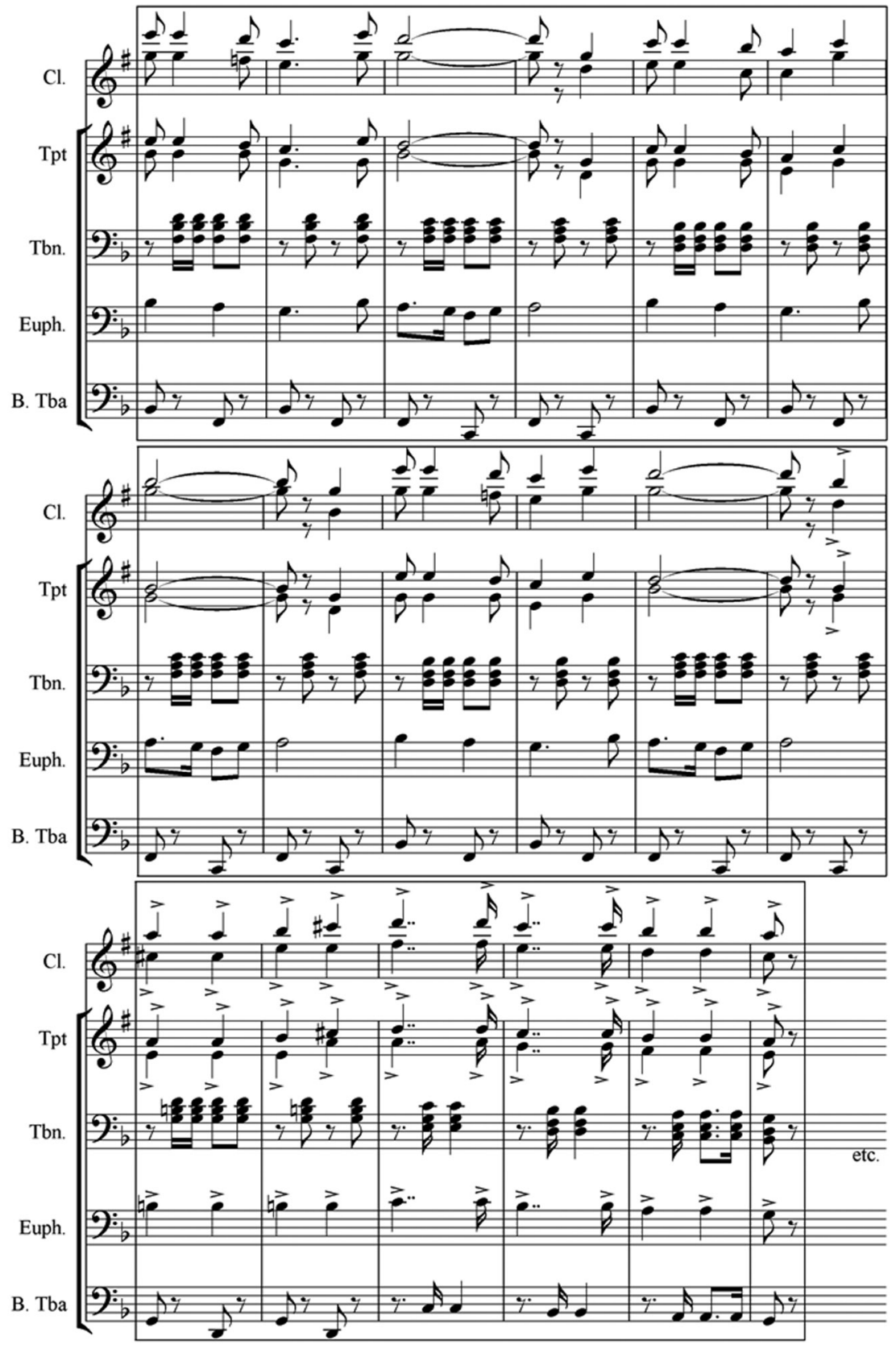


Figure 9a. Theme from Salfiy ad-Dhaläm.
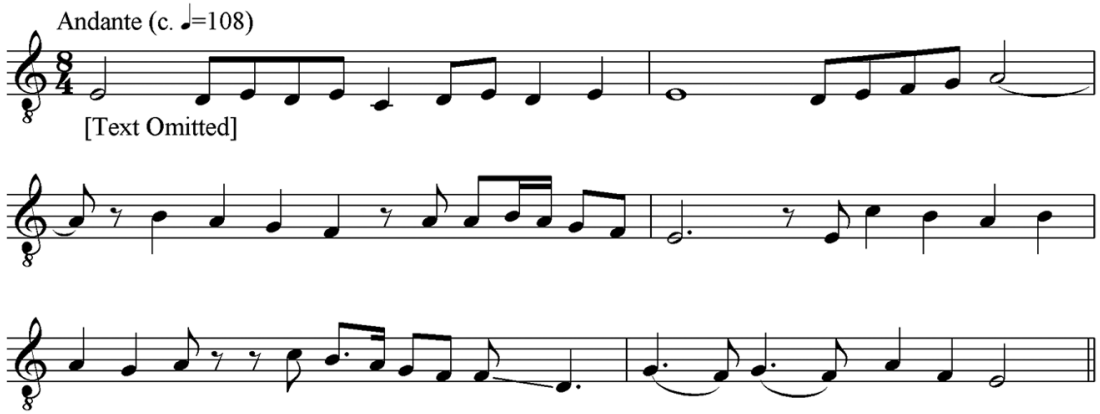

Figure 9b. Extract from the first strain of the March, showing the transformation of a theme from Muwashshah Salify ad-Dhaläm.
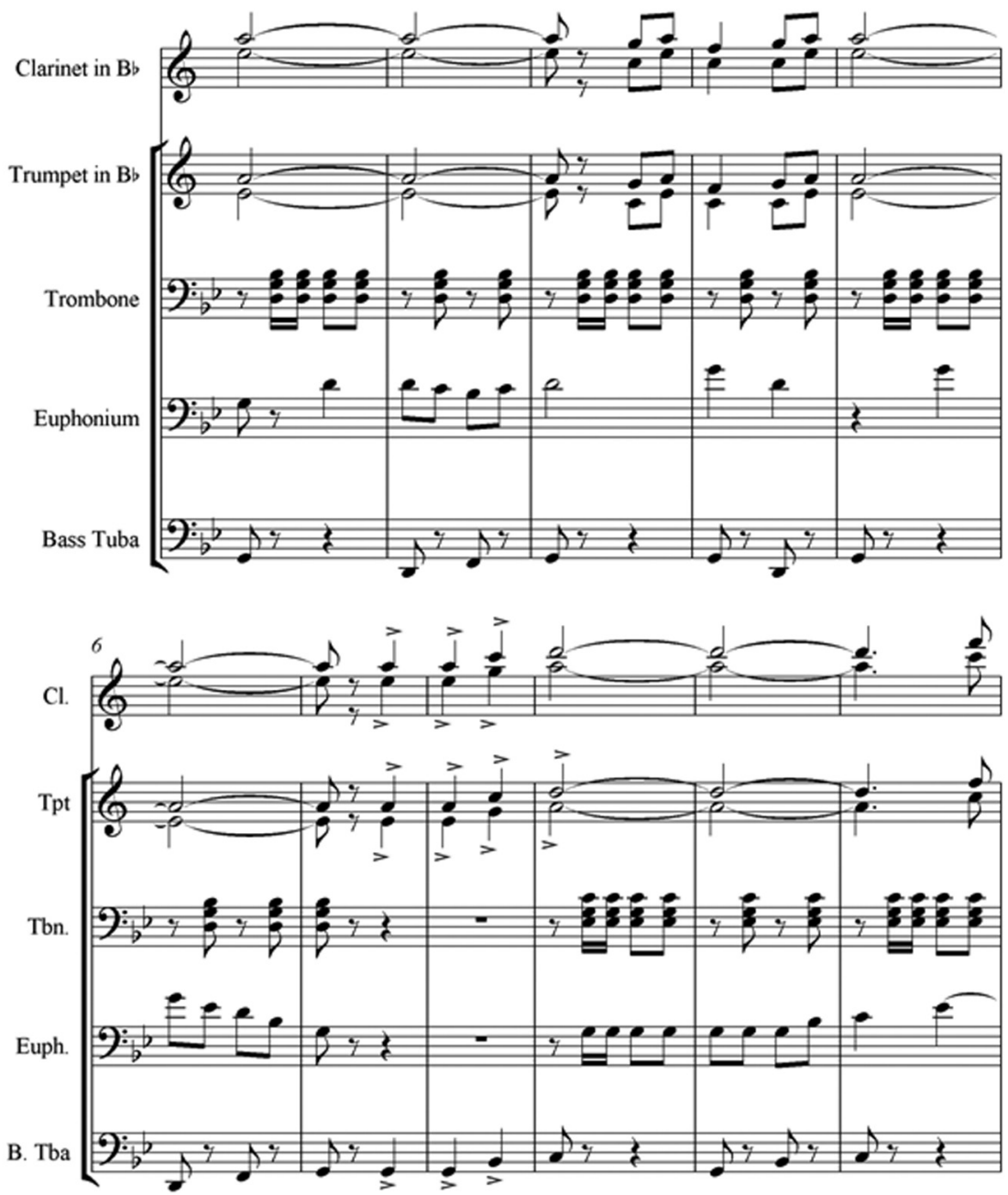
Figure 9b. (cont.)
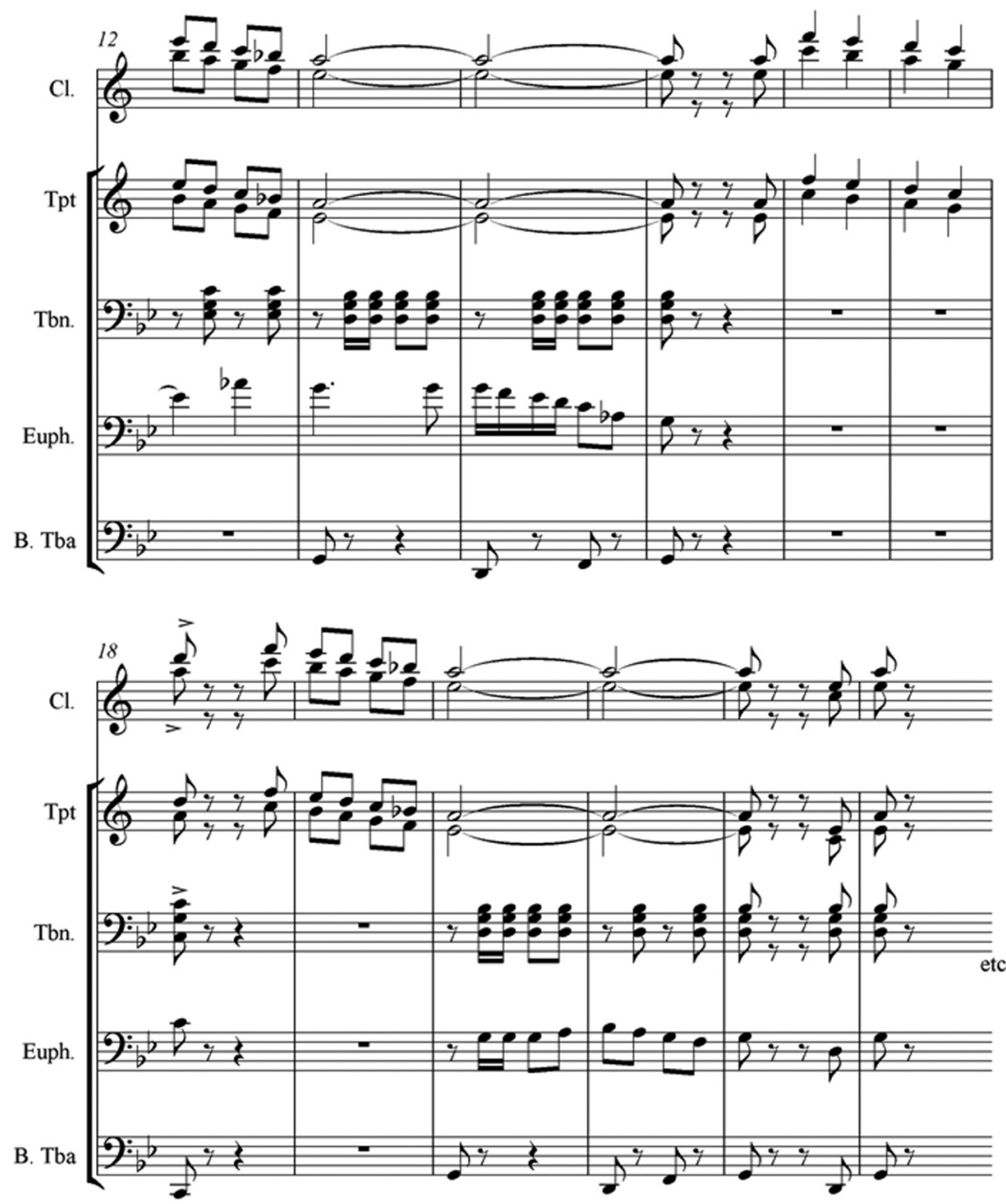

al-Jadiyd recording studio. Such circumstances led me to focus on this piece, and particularly on its opening theme. From the first time I heard this theme I had envisaged it as a melody suitable for a Maltese march, due mainly to its mellow melodic character, which is typical of the first section in Maltese marches. Such a section provides an effective contrast with the pompous and highly engaging character of the introduction. Slight adjustments to the original theme included the weeding out of "ornamentation" to bring out its "singability," eventually making it a catchy tune with a good prospect of being matched to some appropriate text later (see Figure 9b). In contrast with the mellow character of this theme, the 
acclamation-like character of another, also from nawba jamru l-hawā (see Figure 10a), seemed to me a "natural" fit to the strongly-marked bass passage characteristic of the second strain in Maltese marches (see Figure 10b). All the above modifications-very much inspired by an insider's knowledge of his own music tradition, the cynicism of the transforming process, and interaction with the underlying politics of "otherness" in the context of European Malta-brought with them a kind of aesthetic enjoyment rooted in the pleasure of "knowing what has been preserved as well as what has been changed, shifted, or omitted" (Tenzer 2000:424).

\section{Reception and the Mediated Self}

In an attempt to get some initial feedback and further assess the issue being discussed here, I sent a midi-file version of the march to ten Maltese colleagues and friends, including composers both of Maltese marches and of other genres, bandsmen, festa aficionados, and scholars in oriental studies. ${ }^{19}$ Their reactions to it varied according to the domain and musical proficiency of each, with responses ranging from detailed analytical considerations to just some overall impressions. The march was presented to them as a newly composed festa march without any title or information that could have prejudiced their responses. In taking this approach, I was mainly interested in receiving reactions about the degree of "exoticness" that I had embedded in the march (if any had been felt) and whether it had fit well with the musical style into which it was implanted. I gave my listeners no pre-set questions, asking them only to write informally back to me with any comments they deemed useful.

Eight of the ten respondents heard a Middle Eastern influence in the march, especially in the first three sections, where the use of minor tonalities was predominant, with comments such as: "a Greek-Turkish influence is very evident here especially in the first half"; "its initial sections remind me of that kind of music used in biblical films"; "it's hard not to note the augmented 2nd, so typical of Arab music, in the sections preceding the trio"; "you have a nice tint of Arab music in this march that makes it uncommon in the context of Maltese marches"; "its initial melodies remind me of Egyptian music"; "I associate this music with music from the Arab/oriental world more than a typical Maltese march we're used to hearing in a festa"; "the music sounds quite Eastern-Eastern

Figure 10a. Theme from Nawba Jamru l-Hawā.

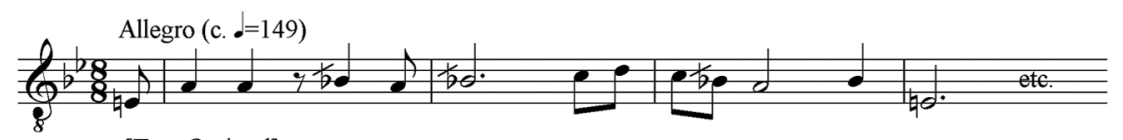

[Text Omitted] 
Figure 10b. A bass passage (in reduced score) with melodic material derived from Nawba Jamru l-Hawā.
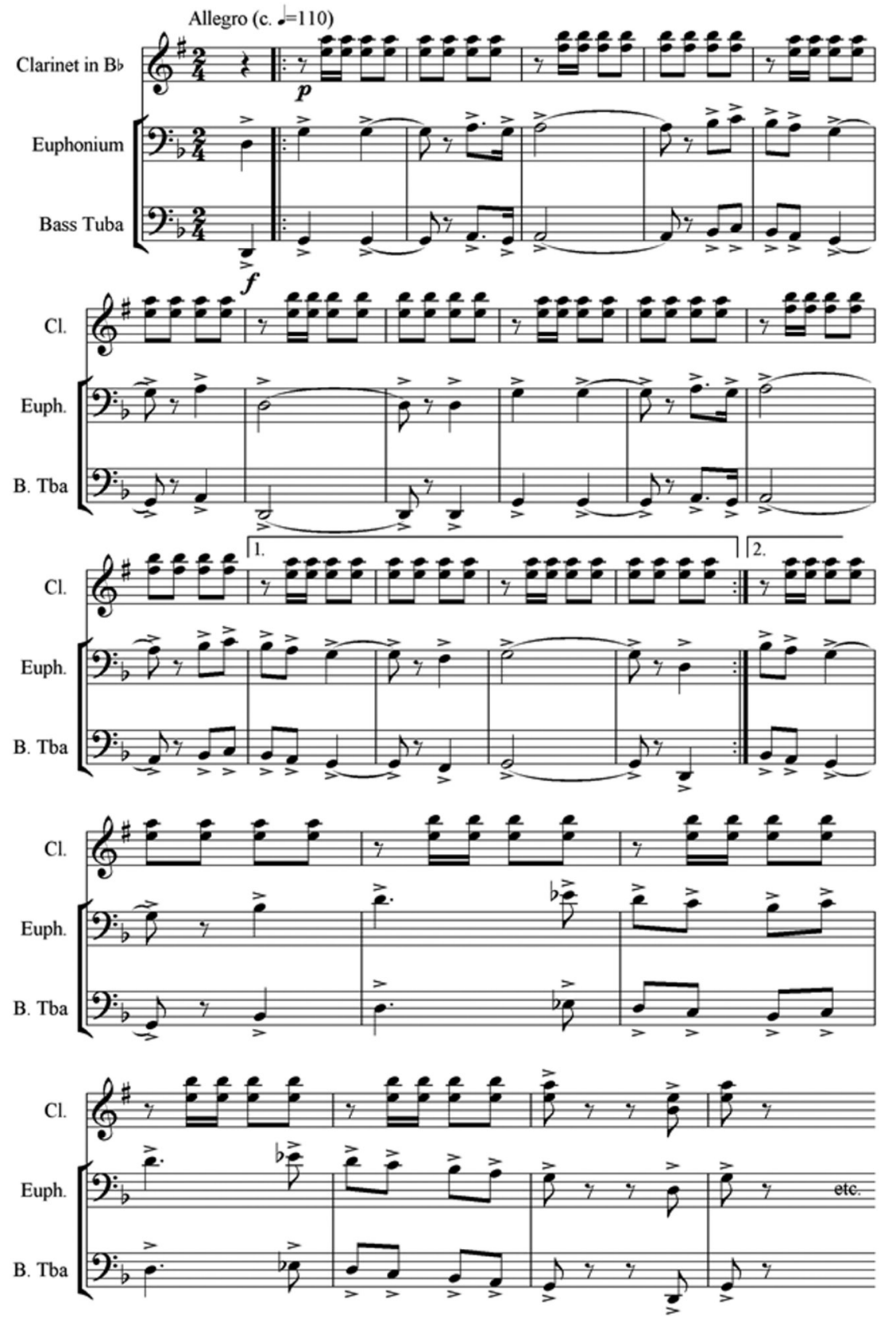
in the Hollywood sense. It would easily fit an old-time epic if I had to rearrange the work for an orchestra"; "there's a nice balance in this march between what is considered as traditional, mainly in its form, and what can be considered as a more adventurous endeavor especially in the inclusion of Middle Eastern melodies" (e-mails, 8-15 April 2012, Malta).

Even if the march in question was considered by most respondents, owing to its oriental flavor, to deviate from the archetypical Maltese festa march, the chosen themes were considered by those who commented on them to be "pleasant to the ear," even if at various degrees: "very singable indeed and, hence, words could easily fit to it"; "the trio section is more singable than the other sections and, therefore, easier to sing along"; "the march is pleasant to the ear, however, it sounds more like a traditional Italian marcia-sinfonica [a symphonic march] rather than a typical Maltese festa march. Its initial sections sound somewhat serious to me in comparison to what we hear in Maltese marches"; "the melodies are very pleasant; though it's not a march to which you would fit words but a march that you just enjoy listening to"; "it's nice music but it lacks the merriment we're used to in the typical Maltese march" (ibid.).

How the translated product is understood on the reception side says a lot about the way its sonic representation of "otherness" is decoded and systematized according to conceptions of what constitutes the archetypical. All this paves the way to further political maneuvering the area of acceptance of "otherness"-a kind of strategy strongly characterized by interpretation of the misinterpreted, with interlinks to issues concerning innovation, compliance, and the borders in-between.

Whatever the case, the ethnomusicologist-as-composer, the composer-asethnomusicologist, and the listener are at every stage detached from neither the personal history that makes them nor the internal and the external worlds that mold their consciousness. Each person's degree of readiness to become involved in the complex process of cultural translation in general and musical translation in particular is determined by the degree to which the individual harmonizes with his or her own self, while reconciling it and all that makes it with the world outside and its impact on him or her. This suggests Michael Tenzer's experiences as an ethno-composer employing kebyar music in his compositions, endeavoring to imagine connections between kebyar and Western music. Such imagination became an internal reconciliation that was channeled into new compositions:

Throughout my study in Bali I sought ways to view kebyar and Western music, particularly new music, as interrelated. I perused scores and tapes of chamber and orchestral music at night, imagining connections to the music I was learning daily in the equatorial heat ....I was impelled to work toward an internal reconciliation of the two worlds. (2000:387-88) 
Imagination is of utmost importance to musical translation, since it can generate sentiments that are profoundly political as well as musical. For instance, the musical style into which music is translated may possess, under certain circumstances, a social and, therefore, a political function. This has been rightly observed by Tenzer with reference to the compositions of Filipino concert pianist, composer, and ethnomusicologist José Maceda (1917-2004), about whom, among other things, he notes the following:

Maceda came to envision the language of Varèse and Xenakis as a vehicle that could be reharnessed to serve a different culture and way of life. Viewed this way, avant-garde music could take on a progressive social function in the Philippines by articulating the repressed voices and aesthetics of its marginalized peoples in a reinvigorating modern way. Maceda hoped, in other words, that insofar as Varèse had undone the inherent Westerness of the avant-garde, then such music could be in effect a slate on which Maceda could inscribe traditional Southeast Asian values, thereby disseminating them more broadly than ever before. (2003:100)

Maceda's case indicates the potential for the ethno-composer to carry the compositional process into the arena of social activism, even if not necessarily at the pragmatic level in its strictest sense. After all, ethnomusicology is in itself a social discipline very much concerned with articulating the voices of the unvoiced, and musical translation is sometimes indispensable in making this happen. This can only take place, however, in the context of sometimes diametrically opposing currents mediated by the self-whether ethnomusicologist, ethnocomposer, or listener.

\section{Conclusion}

In this article I have argued that musical translation is a process strongly influenced, and sometimes even determined, by a spectrum of other interrelated processes and considerations, ranging from those related to style and structure to others concerned with modes of interaction both with the music at home and the one away. Other processes relate to the intrinsic musical character of a theme, the translator's motivation to embark on and resume with the translation, and the interrelationship of these factors with the translator's personal recollections of the past and aspirations for the future. All these considerations are potentially capable of nurturing, directing, redirecting, and shaping the entire process of musical translation. Viewed in this way, such a process emerges as another form of musical participation, especially given Finnegan's statement that "people participate in music in multifarious ways in the different roles they take, the occasion, or their own personal histories ..." (2003:189).

Like other modes of musical participation, musical translation is highly 
dependent on who we are and how we perceive the world around us, the strategies we follow in order to make sense of the "otherness," and eventually the reallocation of that "otherness" in what Turino (2008:7) refers to as "the internal context of the perceiver" (i.e., the personal history and experience of individuals). Scrutinizing the individual is of utmost importance at this stage, since it provides us with the chance to focus on the personal, the idiosyncratic, and the unusual-these, inevitably, being "part of the collective, the typical, and the ordinary" (Stock 1996:2). An understanding of how, over time, "music is individually created and experienced" (Rice 1994:8) on the border between the self and the other will definitely assist us in evaluating from a somewhat different perspective "the self's encounter with [diverse] musical symbols in the world" (ibid.:4) and how these come together, attain meaning, and eventually transform the same meaning within the particularity of individual consciousness.

The interrelated processes described above lie on the border between the self and the other; the border itself therefore becomes a fertile land for the generation and regeneration of further issues, with the individual, and the consciousness that shapes them, playing a central role at all stages of the discussion. The self is determinant in all this, and, apart from being highly active in related psychological processes mainly prompted by the challenges of understanding new cultural experiences and the demands of intercultural contacts, participates in a process that Clifford (1997:182) describes as anything but neutral: "Cross-cultural translation is never entirely neutral: it is enmeshed in relations of power. One enters the translation process from a specific location, from which one only partly escapes."

The present essay has shown how individual histories are shaped by the power that lies in individual life circumstances, the obligations we enter into with our own music cultures, our feelings about both the musical traditions to which we belong and those in which we find ourselves, the motivations that keep us going, the forms of representation we interact with and are willing to interpret, and, of equal importance, the recordings, people, and places we experience throughout. While the processes described above emerged on a continuum of considerations and decision-making that eventually led to the making of the band march in question, the central figure here remains the perceiver and the nature of his or her "internal context." This reminds us of the medieval scholastic axiom Quidquid recipitur ad modum recipientis recipitur - "Whatever is received is received according to the mode of the receiver." In other words, whatever we perceive is likely to be forged more by who we are than by the qualities of what we perceive. By extension, scrutinizing the musical translation process can be a good way for ethnomusicologists to analyze the reality underlying the actively distorted perceptions that arise from the very act of understanding, appreciating, and describing the music of the "others." Moreover, musical translation and our investigation of it can say a lot about who we are and what permits or hinders our assimilation of realities that we might feel do not pertain to our own consciousness. 


\section{Notes}

An earlier version of this paper was read during the Mediterranean Music Studies ICTM Study Group conference "Musical Translations Across the Mediterranean," held in Malta on 1-4 July 2010.

1. Malta is a Mediterranean island country with a population of around 400,000. It lies in between Southern Italy and North Africa. For further reading on Maltese music see Ciantar (2005a); Ciantar and Moore (2001); JaFran Jones (2000).

2. While in Libya, Tunisia, and Eastern Algeria the North African nawba repertoire is known as $m a^{\prime} l \bar{u} f$, that of Morocco is known as äla (song with instrumental accompaniment), that of Algiers san'a (work of art), and that of Western Algeria garnātì (from Granada).

3. For an overview of the musical activity in Tripoli (Libya) see Ciantar (2005b). Additional reading on Libyan music more generally can be found in El Sibaei (1981), Brandily (2001), and Ciantar and Sebai (2005).

4. For more comprehensive reading about the Libyan ma'lūf see Ciantar (2002a, 2002b, 2012) and El Sebaei (2001).

5. Autoethnography here refers to that form of writing that "make[s] the researcher's own experience a topic of investigation in its own right" (Ellis and Bochner 2000:733). Autoethnography is "an autobiographical genre of writing that displays multiple layers of consciousness, connecting the personal to the cultural" (ibid.:739), with autoethnographers asking "their readers to feel the truth of their stories and to become coparticipants, engaging the storyline morally, emotionally, aesthetically, and intellectually" (ibid.:745).

6. See also the following: http://www.ischiamusica.com/programmi/etnomusicologia_2011.pdf (accessed 2 May 2012).

7. In this other shade of the term "translation," as understood in the anthropological sense, "an ethnographer is always interpreting and translating into text what [s/he] sees" (Emerson et al. 1995:16). As such, "the writer not only translates concepts but also a whole way of life for a future audience who may not be familiar with the world [s/he] describes" (ibid.).

8. The sympathy of certain band clubs to one of the main Maltese political parties, although not always as evident as it was in the past, still exists. Sometimes such political sympathies are evident during the morning band parade on festa day, when aspiring and/or prominent district politicians or aspiring candidates for the general election are carried high on supporters' shoulders to the accompaniment of loud music of marches played by the band. In many instances, band club committees have served as a springboard from which prominent persons in the village have stepped into national politics and gained electoral popularity.

9. In some villages, formal agreements have been reached between opposing clubs, with the church and high-profile trusted personalities in the village serving as mediators.

10. For further reading about the Tunisian ma'lüf see Davis (2004).

11. In fact, the ma'lūf al-idhāa is closest to what came to be the dominant form in Tunisian $m a ' l u ̈ f$ (i.e., a secular "art music" type of performance).

12. For a more focused discussion about musical change in the Libyan ma'lüf see Ciantar 2003.

13. For an extensive discussion of the role of sheiks in the Libyan malüf tradition and their impact on current listening to the same music, see Ciantar (2006).

14. For a more insightful discussion of this issue see Sant Cassia (2000).

15. The $g \hbar$ is soundless in Maltese.

16. I would like to thank my brother Michael Ciantar, himself a composer of festa band marches, for pointing out this to me.

17. The other meter commonly employed in Maltese marches is ${ }_{8}^{6}$.

18. This example is transposed a semitone lower than it actually sounds on the recording.

19. This feedback exercise was carried out in April 2012. I would like to thank the following colleagues and friends for their written feedback to my midi-file version of the march: Gordon 
Zammit, Tancred Grech, Peter Paul Ciantar, Joseph Chircop, Patrick Ciantar, Martin Zammit, Kevin Mizzi, Ruth Bonello, Godfrey Mifsud, and Mark Farrugia.

\section{References}

Beck, Robert C. 1978. Motivation: Theories and Principles. Englewood Cliffs, NJ: Prentice-Hall. Bohlman, Philip V. 2002. World Music: A Very Short Introduction. New York: Oxford University Press.

Boissevain, Jeremy. 1964. "Factions, Parties and Politics in a Maltese Village." American Anthropologist 66:1275-87.

. 1990. "More Music for the Saints: Religious Feasts in Malta. The World \& I (May):145-59. 1993. Saints and Fireworks: Religion and Politics in Rural Malta. Valletta: Progress Press.

Brandily, Monique. 2001. "Libya." In The New Grove Dictionary of Music and Musicians, 2nd ed., vol. 14, edited by Stanley Sadie, 649-51. London: Macmillan Publishers Ltd.

Chion, Michel. 2000. "Audio-Vision and Sound." In Sound, edited by Patricia Kruth and Henry Stobart. 201-21. Cambridge: Cambridge University Press,.

Ciantar, Philip. —. 2002a. "Libya and Its Andalusian Musical Heritage." The Malta Independent on Sunday, September 1, Gallarija 7.

_. 2002b. "Hassan Araibi and the Libyan Ma'lūf Musical Tradition." The Sunday Times of Malta, October 6, Music 36.

—_ 2003. "Continuity and Change in the Libyan Ma'lüf Musical Tradition." Libyan Studies 34:137-46.

. 2005a. "Malta." In Continuum Encyclopedia of Popular Music of the World. Vol. 7: Europe, edited by John Shepherd, David Horn, and Dave Laing, 258-62. London and New York: Continuum.

—. 2005b. "Tripoli’s Musical Soundscape: Experiences and Meanings." Libyan Studies 36:79-88. - 2006. "Nostalgia, History and Sheikhs in the Libyan Ma'luff: Listening Contexts in the Shadows of the Past." In Muwashshah: Proceedings of the Conference on Arabic and Hebrew Strophic Poetry and its Romance Parallels, School of Oriental and African Studies [SOAS], London, 8-10 October 2004, edited by Ed Emery, 55-70. London: RN Books.

- 2012. The Ma'lüfin Contemporary Libya: An Arab Andalusian Tradition. Farnham: Ashgate. Ciantar, Philip, and Sylvia Moore. 2001. "Malta [Traditional]." In The New Grove Dictionary of Music and Musicians, 2nd ed., vol. 12, edited by Stanley Sadie, 233-41. London: Macmillan Publishers Ltd.

Ciantar, Philip, and Abdalla M.Sebai. 2005. "Libya." In Continuum Encyclopedia of Popular Music of the World. Vol. 6: Africa and the Middle East, edited by John Shepherd, David Horn, and Dave Laing, 67-70. London and New York: Continuum.

Clifford, James. 1986. "On Ethnographic Allegory." In Writing Culture: The Poetics and Politics of Ethnography, edited by James Clifford and George E. Marcus, 98-121. Berkeley: University of California Press.

.1997. Routes: Travel and Translation in the Late Twentieth Century. Cambridge, MA: Harvard University Press.

Davis, Ruth F. 2004. Ma'lūf: Reflections of the Arab Andalusian Music of Tunisia, Lanham, MD: Scarecrow Press.

Dibben, Nicola. 2003. "Musical Materials, Perception and Listening." In The Cultural Study of Music: A Critical Introduction, edited by Martin Clayton, Trevor Herbert, and Richard Middleton, 193-203. New York and London: Routledge.

Ellis, Carolyn, and Arthur P. Bochner. 2000. "Autoethnography, Personal Narrative, Reflexivity: Researcher as Subject." In The Handbook of Qualitative Research, 2nd ed., edited by Norman K. Denzin and Yvonna S. Lincoln, 733-68. Thousand Oaks, CA, and London: Sage. 
Emerson, Robert M., Rachel I. Fretz, and Linda L. Shaw. 1995. Writing Ethnographic Fieldnotes. Chicago and London: The University of Chicago Press.

Finnegan, Ruth. 2003. "Music, Emotion and the Anthropology of Emotion." In The Cultural Study of Music: A Critical Introduction, edited by Martin Clayton, Trevor Herbert, and Richard Middleton, 181-92. New York and London: Routledge.

Garzia Álvarez, Ana María. 2007. “Evaluating Students’ Translation Process in Specialised Translation: Translation Commentary." The Journal of Specialised Translation 7:139-63. http://www .jostrans.org/issue07/art_alvarez.php (accessed 20 April 2012).

Holmes, James S. 2000. "The Name and Nature of Translation Studies." In The Translation Studies Reader, edited by Laurence Venuti, 173-85. London: Routledge.

Jones, L. JaFran. 2000. "Malta." In The Garland Encyclopedia of World Music, Vol. 8: Europe, edited by Timothy Rice, James Porter, and Chris Goertzen, 634-43. New York and London: Garland Publishing, Inc.

Kim, Young Yun. 2000. "On Becoming Intercultural." In AmongUs: Essays on Identity, Belonging, and Intercultural Competence, edited by Myron W. Lustig and Jolene Koester, 59-67. New York: Longman.

Powers, Harold S. 1980. "Language Models and Musical Analysis." Ethnomusicology 24:1-60.

Rice, Timothy. 1994. May It Fill Your Soul: Experiencing Bulgarian Music. Chicago and London: The University of Chicago Press.

Ricoeur, Paul. 1981. Hermeneutics and the Human Sciences. Edited, translated, and introduced by John B. Thompson. Cambridge: Cambridge University Press.

Sant Cassia, Paul. 2000. "Exoticizing Discoveries and Extraordinary Experiences: 'Traditional' Music, Modernity, and Nostalgia in Malta and Other Mediterranean Societies." Ethnomusicology 44:281-301.

Schafer, R. Murray. 1977. The Tuning of the World. New York: Alfred A. Knopf.

Schwandt, Erich. 2001. "March, I. The Military March to the 1820s." In The New Grove Dictionary of Music and Musicians, 2nd ed., vol. 15, edited by Stanley Sadie, 813. London: Macmillan Publishers Ltd.

Stock, Jonathan P. J. 1996. Musical Creativity in Twentieth-Century China: Abing, His Music and Its Changing Meanings. Rochester, NY: Rochester University Press.

Susam-Sarajeva, Șebnem, ed. 2008. "Translation and Music: Changing Perspectives, Frameworks and Significance." The Translator 14:187-200.

El Sibaei, Abdalla M. 1981. "Traditional and Folk Music as a Vehicle for Music Education in the Libyan Society." M.Mus dissertation, University of Michigan.

—. 2001. Turāth an-Nawba Al-Andalusiyya Fiy Liybyā (The Andalusian Nawba Heritage in Libya). Sabha: Al-Markaz Watiniy lil Māthurāt al-Sha'biya.

Tenzer, Michael. 2000. Gamelan Gong Kebyar: The Art of Twentieth-Century Balinese Music. Chicago: Chicago University Press.

. 2003. "José Maceda and the Paradoxes of Modern Composition in Southeast Asia." Ethnomusicology 47:93-120.

Torop, Peeter. 2003. "Intersemiosis and Intersemiotic Translation." In Translation Translation, edited by Susan Petrilli, 271-82. Amsterdam: Rodopi.

Turino, Thomas. 2008. Music as Social Life: The Politics of Participation. Chicago: University of Chicago Press. 